\title{
Hemophagocytic Syndrome in Patients with Unexplained Cytopenia: Report of 15 Cases
}

\section{Açıklanamayan Sitopenili Olgularda Hemofagositik Sendrom: 15 Olgu Sunumu}

\author{
Heidarali ESMAILI, Omid RAHMANI, Rohollah F FOULADI
}

Department of Pathology, Tabriz University of Medical Sciences, TABRIZ, IRAN

\section{ABSTRACT}

Objective: To investigate the frequency of hemophagocytic syndrome in a series of patients with otherwise unexplained cytopenia.

Material and Method: In this cross-sectional, single-centre study, bone marrow specimens $(n=288)$ were obtained from the patients with unexplained cytopenia. The diagnosis of hemophagocytic syndrome was made according to universally accepted criteria. Characteristics of the patients, as well as the clinical and laboratory findings were reported.

Results: Fifteen cases (5.2\%) fulfilled the hemophagocytic syndrome criteria, including 8 males (53.3\%) and 7 females (46.7\%) with a mean age of $39.7 \pm 20.7$ (range: $14-72$ ) years at the time of diagnosis. The main clinical and laboratory findings were cytopenia (100\%), fever (73.3\%), hyperferritinemia (66.7\%), elevated erythrocyte sedimentation rate $(60 \%)$, hypertriglyceridemia $(60 \%)$, organomegaly (53.3\%), elevated liver enzymes (53.3\%), lymphadenopathy $(26.7 \%)$, neurological symptoms (20\%), and skin rash (13.3\%). Two patients (13.3\%) died before a diagnosis was made.

Conclusion: Our findings indicate that the hemophagocytic syndrome is not a rare pathologic condition in patients with otherwise unexplained cytopenia. Without treatment, the mortality rate may be high.

Key Words: Cytopenia, Lymphohistiocytosis, Hemophagocytic, Prognosis

\section{ÖZ}

Amaç: Başka nedenlerle açıklanamayan sitopenisi olan bir dizi hastada hemofagositik sendrom sıklığını araştırmaktır.

Gereç ve Yöntem: Bu kesitsel ve tek merkezli çalışmada başka nedenlerle açılanamayan sitopenisi olan 228 hastanın $(n=228)$ kemik iliği biopsileri değerlendirilmiștir. Hemofagositik sendrom tanısı genelde kabul görmüş kriterlerle konmuştur. Hastaların özellikleri ve klinik/laboratuvar bulguları kaydedilmiştir.

Bulgular: Sekizi $(\% 53,3)$ erkek ve 7 'si kadın $(\% 46,7)$ olmak üzere ortalama yaşları 14-72 arasında değişen $(39,7 \pm 20,7) 15$ olgunun tanı anında hemofagositik sendrom kriterlerini taşıdığı saptanmıştır. Temel klinik ve laboratuvar bulgular sitopeni $(\% 100)$, ateş $(\% 73,3)$, hiperferritinemi $(\% 66,7)$, yüksek eritrosit sedimentasyon hızı (\%60), hipertrigliseridemi (\%60), organomegali $(\% 53,3)$, yükselmiş karaciğer enzimleri $(\% 53,3)$, lenfadenopati $(\% 26,7)$, nörolojik belirtiler $(\% 20)$ ve deri döküntüleridir $(\% 13,3)$. İki hasta $(\% 13,3)$ tanıdan önce kaybedilmiştir.

Sonuç: Bulgularımız, başka nedenlerle açıklanmayan sitopenisi olan hastalarda hemofagositik sendromun ender rastlanan bir patolojik durum olmadığına işaret etmektedir. Tedavi yapılmazsa mortalite yüksek olabilir.

Anahtar Sözcükler: Sitopeni, Lenfohistiositozis, Hemofagositik, Prognoz

\section{INTRODUCTION}

Hemophagocytic lymphohistiocytosis or hemophagocytic syndrome (HPS) is an uncommon hematologic disorder typically characterized by the activation of macrophages/ histiocytes with notable hemophagocytosis in the bone marrow and other reticuloendothelial systems (1).

The predominant clinical and laboratory features of HPS are fever (often hectic and persistent), cytopenias, hepatitis (elevated liver enzymes), hepatosplenomegaly (organomeg-

(Turk Patoloji Derg 2013, 29:15-18)

Received : 07.10.2012 Accepted : 27.11.2012 aly), lymphadenopathy, coagulopathy, lymphocytosis and histiocytosis. HPS can be categorized as primary (familial/ hereditary) or secondary (reactive/acquired) subtypes (2).

Secondary HPS is believed to be associated with various conditions such as malignancies, autoimmune diseases, certain drugs, hematopoietic stem cell or organ transplantations, and infections (Epstein-Barr virus in particular) $(3,4)$.

Correspondence: Omid RAHMANI

Department of Pathology, Tabriz University of Medical Sciences, Imam Reza Hospital, TABRIZ, IRAN

E-mail: medicorelax3@yahoo.com Phone: +98914412 2542 
Although HPS is usually regarded as a rare condition, to the best of our knowledge, there is not sufficient relevant data available in the literature except for a limited number of case reports (5-8).

This lack of data is even more significant when it is born in mind that the prognosis of the patients with HPS is not very good, particularly when left untreated. It is shown that early recognition and aggressive treatment of HPS may change a uniformly fatal disease to one with a $55 \%$ rate of survival (9).

As cytopenia is a key finding in the cases with HPS (10), the main objective of this study was to examine a series of patients with otherwise unexplained cytopenia in terms of the frequency of HPS.

\section{MATERIAL and METHODS}

In this cross-sectional study, 1388 consecutive specimens from the bone marrow obtained by biopsy/aspiration were evaluated in a referral teaching hematology-oncology centre from April 2007 through April 2010.

This study was performed according to the principles of the World Medical Association Declaration of Helsinki. Informed consent was obtained from all participants.

Two hundred eighty eight specimens (20.7\%) belonged to patients with otherwise unexplained cytopenia after thorough clinical and paraclinical investigations.

HPS was diagnosed based on the criteria reported by Henter et al. (10), summarized in Table I.

All the specimens were examined by a skilled pathologist with over 20 years experience by light microscopy under proper magnification after appropriate preparation and staining (hematoxylin and eosin staining protocol for paraffin embedded biopsy specimens, Giemsa's staining protocol for touch smear and aspiration specimen, (Figure $1)$.

The patients' characteristics, as well as clinical and laboratory findings were recorded.

Statistical analysis was performed using SPSS Software version 15.0 (Chicago, USA). The results were expressed as mean \pm standard deviation or frequency $(\%)$.

\section{RESULTS}

Fifteen patients out of 288 cases with unspecific cytopenia were reported to be effected with HPS (Figure 2).

Eight patients were male (53.3\%) and 7 patients were female (46.7\%) with a mean age of $39.7 \pm 20.7$ (range: $14-72$ ) years at the time of diagnosis (Figure 3).
The clinical and laboratory findings in patients with HPS are summarized in Table II.

The major findings in the microscopic examination of the bone marrow specimens obtained from the patients with HPS were megaloblastic anemia $(n=2)$, chronic granulomatous disease $(n=1)$, and bone marrow sea-blue histiocyte syndrome $(n=1)$.

Table I: Diagnostic criteria for hemophagocytic syndrome

\begin{tabular}{|l|}
\hline 1. Familial disease/known genetic defect \\
\hline 2. Clinical and laboratory criteria $(\mathbf{5} / \mathbf{8}$ criteria $)$ \\
\hline${ }^{\star}$ Fever \\
\hline${ }^{\star}$ Splenomegaly \\
\hline${ }^{\star}$ Cytopenia $=>2$ cell lines \\
\hline Hemoglobin $<90 \mathrm{~g} / \mathrm{l}$ (below 4 weeks $<120 \mathrm{~g} / \mathrm{l})$ \\
\hline Platelets $<100 \cdot 109 / 1$ \\
\hline Neutrophils $<1 \cdot 109 / 1$ \\
\hline${ }^{\star}$ Hypertriglyceridemia and/or hypofibrinogenemia \\
\hline Fasting triglycerides $=>3$ mmol/l \\
\hline Fibrinogen $<1.5 \mathrm{~g} / 1$ \\
\hline${ }^{\star}$ Ferritin $>500 \mu \mathrm{g} / \mathrm{l}$ \\
\hline${ }^{*} \mathrm{SCD} 25=>2400 \mathrm{U} / \mathrm{ml}$ \\
\hline${ }^{\star}$ Decreased or absent NK-cell activity \\
\hline $\begin{array}{l}{ }^{*} \text { Hemophagocytosis in bone marrow, CSF or lymph } \\
\text { nodes }\end{array}$ \\
\hline
\end{tabular}

From Schneider et al (10).

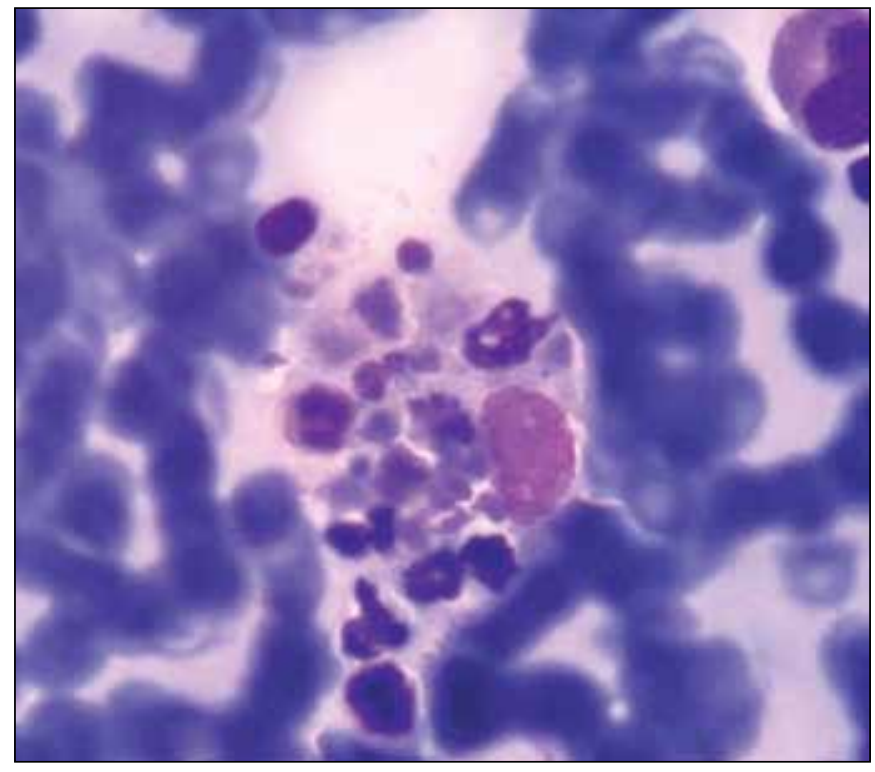

Figure 1: Hemophagocytosis in the bone marrow aspirate (Giemsa, x40). 


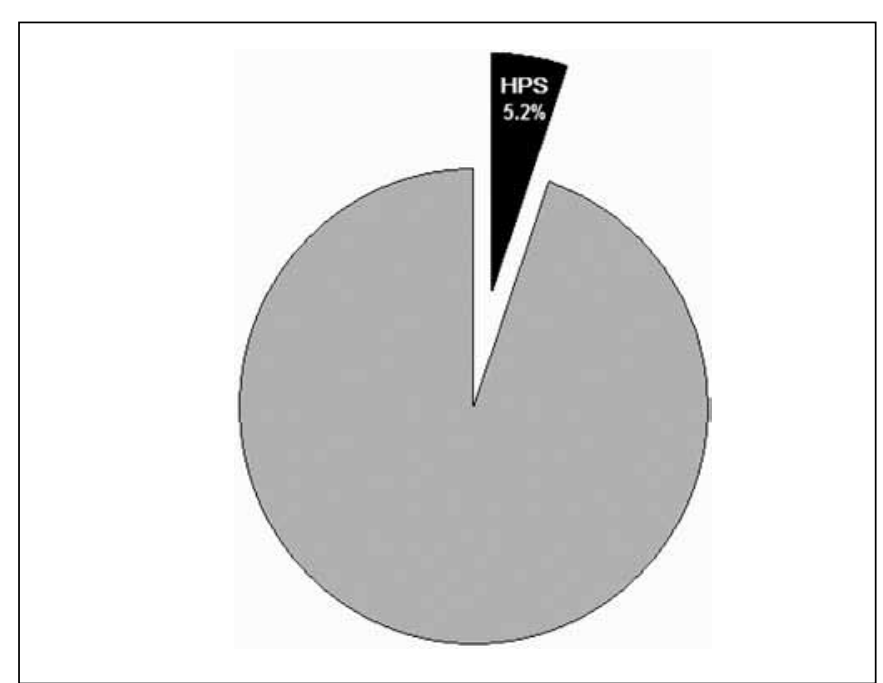

Figure 2: Percentage of the cases with hemophagocytic syndrome among the patients with unexplained cytopenia (HPS: hemophagocytic syndrome).

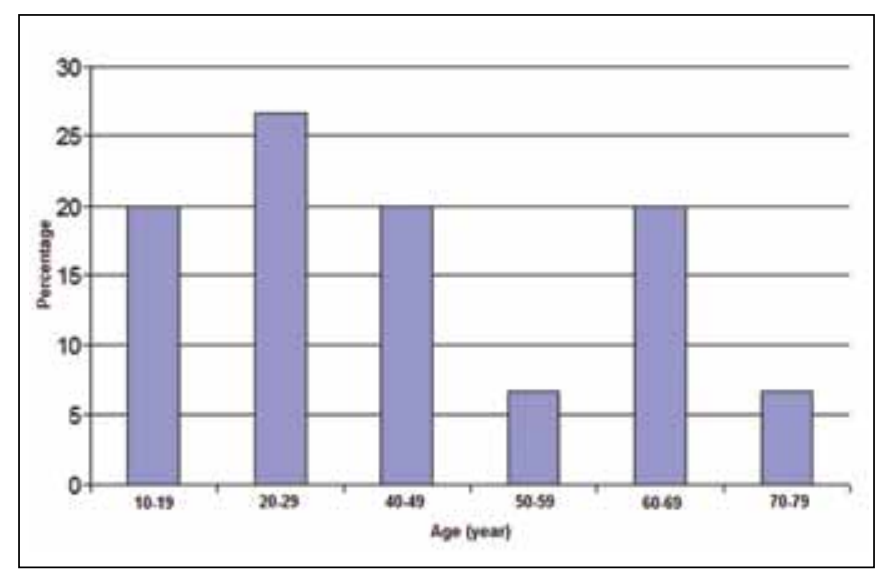

Figure 3: Percentage of the cases with hemophagocytic syndrome among the patients with unexplained cytopenia stratified by age groups.

Table II: Clinical and laboratory findings in the patient with hemophagocytic syndrome

\begin{tabular}{|l|c|c|}
\hline Finding & n & \% \\
\hline Cytopenia & 15 & 100 \\
\hline Fever & 11 & 73.3 \\
\hline Hyperferritinemia & 10 & 66.7 \\
\hline Elevated ESR & 9 & 60.0 \\
\hline Hypertriglyceridemia & 9 & 60.0 \\
\hline Organomegaly & 8 & 53.3 \\
\hline Elevated liver enzymes & 8 & 53.3 \\
\hline Lymphadenopathy & 4 & 26.7 \\
\hline Neurological symptoms & 3 & 20.0 \\
\hline Rash & 2 & 13.3 \\
\hline
\end{tabular}

ESR: erythrocyte sedimentation rate.
In terms of bone marrow cellularity, there were 9 cases (60\%) with normocellularity, 5 cases (33.3\%) with hypercellularity and 1 case $(6.7 \%)$ with hypocellularity.

Two patients (13.3\%) died before the diagnosis of HPS was made. The remaining patients were discharged after appropriate management.

\section{DISCUSSION}

This series showed that almost $5 \%$ of the patients with otherwise unexplained progressive cytopenia suffer from HPS. Although the cytopenia is a key finding in patients with HPS, to our knowledge there is no report about the real frequency of this condition among patients with unexplained cytopenia.

In a series by Fukaya et al., 1014 inhospital patients with systemic autoimmune diseases were evaluated as to the presence of HPS. Finally, 30 patients (2.3\%) fulfilled the HPS criteria (11).

The male to female ratio was 1.1 in our study. This finding is in line with the previous reports indicating that there is no obvious gender preponderance in cases with HPS $(12,13)$.

The mean age of the patients was $39.7 \pm 20.7$ (range: 1472 ) years in the present study, with the most common age group 20-29 years. In another study by Ishii et al., the age distribution showed a peak of autoimmune disease- and infection-associated HPS in children, while familial type and lymphoma-associated HPS occurred almost exclusively in infants and the elderly, respectively (14). Thus, it seems that the age of the patients is a key determiner of the type of HPS.

It should be noted that the possible underlying causes of HPS were not investigated in our study, because it was not part of our objectives. However, the cases with primary HPS were apparently not included because there was another referral centre specialized in pediatric hematologic/oncologic disorders in the region which did not participate in the present study. Further multicenter studies are possibly indicated in this regard to have more definite conclusions drawn.

The main clinical and laboratory findings of the studied patients with HPS were cytopenia, fever, hyperferritinemia, elevated erythrocyte sedimentation rate (ESR), hypertriglyceridemia, organomegaly, deranged (raised) liver enzymes, lymphadenopathy, neurological symptoms, and rash in a decreasing order of frequency. All these findings are in conformity with previous reports $(12,15)$ except for elevated ESR, indicating a role of inflammatory 
process in some of the patients. This needs to be clarified in further studies.

Before HPS was confirmed and an appropriate therapy started, two patients (13.3\%) with HPS died in our series. On the other hand, all the remaining 13 patients were discharged after receiving sufficient treatment. Hence, it may be concluded that first, HPS carries a significant mortality rate if left untreated; and second, HPS is still a great challenge to be timely diagnosed $(16,17)$.

In summary, although HPS is generally considered as a rare entity, the current study showed that this may not be quite accurate at least among patients with otherwise unexplained cytopenia. Likewise, the patients with HPS are possibly a high risk group for early mortality if left untreated (18). As a consequence, it seems wise for all patients with unexplained cytopenia to undergo a thorough examination for possible presence of HPS.

To the best of our knowledge, this is the first study that deals with the association between unexplained cytopenia and HPS. Due to the heterogeneity of the disease, particularly in terms of its characteristics (14), as well as the race and ethnicity of the patients (9), further controlled investigations may be warranted to have the issue elucidated.

\section{REFERENCES}

1. Imashuku S: Differential diagnosis of hemophagocytic syndrome: Underlying disorders and selection of the most effective treatment. Int J Hematol 1997, 66:135-151

2. Filipovich AH: Hemophagocytic lymphohistiocytosis (HLH) and related disorders. Hematology Am Soc Hematol Educ Program 2009, 127-131

3. Dhote R, Simon J, Papo T, Detournay B, Sailler L, Andre MH, Dupond JL, Larroche C, Piette AM, Mechenstock D, Ziza JM, Arlaud J, Labussiere AS, Desvaux A, Baty V, Blanche P, Schaeffer A, Piette JC, Guillevin L, Boissonnas A, Christoforov $B$ : Reactive hemophagocytic syndrome in adult systemic disease: Report of twenty-six cases and literature review. Arthritis Rheum 2003, 49:633-639

4. Boelens JJ, Lazo G, Gaiser JF, Wulffraat NM: Epstein-Barr virusassociated haemophagocytic lympho-histiocytosis after stem cell transplantation. Bone Marrow Transplant 2006, 38:709-710

5. Machaczka M, Vaktnäs J, Klimkowska M, Nahi H, Hägglund H: Acquired hemophagocytic lymphohistiocytosis associated with multiple myeloma. Med Oncol 2011, 28:539-543
6. Burns S, Saylors R, Mian A: Hemophagocytic lymphohistiocytosis secondary to Ehrlichia chaffeensis infection: A case report. J Pediatr Hematol Oncol 2010, 32:e142-e143

7. Woods AG, Woods CW: Hemophagocytic lymphohistiocytosis in the premature neonate: A case study. Adv Neonatal Care 2009, 9:274-278

8. Nogueira MV, Vidal L, Terra B, Pagot T, Salluh JI, Soares M: Hemophagocytic syndrome associated with cytomegalovirus infection in a severely immunocompromised AIDS patient: Case report. Braz J Infect Dis 2009, 13:72-73

9. Niece JA, Rogers ZR, Ahmad N, Langevin AM, McClain KL: Hemophagocytic lymphohistiocytosis in Texas: Observations on ethnicity and race. Pediatr Blood Cancer 2010, 54:424-428

10. Henter JI, Horne A, Aricó M, Egeler RM, Filipovich AH, Imashuku S, Ladisch S, McClain K, Webb D, Winiarski J, Janka G: HLH-2004: Diagnostic and therapeutic guidelines for hemophagocytic lymphohistiocytosis. Pediatr Blood Cancer 2007, 48:124-131

11. Fukaya S, Yasuda S, Hashimoto T, Oku K, Kataoka H, Horita T, Atsumi T, Koike T: Clinical features of haemophagocytic syndrome in patients with systemic autoimmune diseases: Analysis of 30 cases. Rheumatology (Oxford) 2008, 47:1686-1691

12. Henter JI, Elinder G, Söder O, Ost A: Incidence in Sweden and clinical features of familial hemophagocytic lymphohistiocytosis. Acta Paediatr Scand 1991, 80:428-435

13. Suzuki N, Morimoto A, Ohga S, Kudo K, Ishida Y, Ishii E: Characteristics of hemophagocytic lymphohistiocytosis in neonates: A nationwide survey in Japan. J Pediatr 2009, 155: 235-238

14. Ishii E, Ohga S, Imashuku S, Yasukawa M, Tsuda H, Miura I, Yamamoto K, Horiuchi H, Takada K, Ohshima K, Nakamura $S$, Kinukawa N, Oshimi K, Kawa K: Nationwide survey of hemophagocytic lymphohistiocytosis in Japan. Int J Hematol 2007, 86:58-65

15. Dapena Díaz JL, Díaz de Heredia Rubio C, Bastida Vila P, Llort Sales A, Elorza Alvarez I, Olivé Oliveras T, Sánchez de Toledo Codina J: Haemophagocytic syndrome: A common pathogenic mechanism of various aetiologies. An Pediatr (Barc) 2009, 71:110-116

16. Janka G: Hemophagocytic lymphohistiocytosis: When the immune system runs amok. Klin Padiatr 2009, 221:278-285

17. Créput C, Galicier L, Buyse S, Azoulay E: Understanding organ dysfunction in hemophagocytic lymphohistiocytosis. Intensive Care Med 2008, 34:1177-1187

18. Gupta AA, Tyrrell P, Valani R, Benseler S, Abdelhaleem M, Weitzman S: Experience with hemophagocytic lymphohistiocytosis/macrophage activation syndrome at a single institution. J Pediatr Hematol Oncol 2009, 31:81-84 